Research Article

\title{
Violations of International Humanitarian Law: Threats to Non- combatants in the Syrian Crises, 2011-2020
}

\author{
Ahmed Alameldeen ${ }^{1}$, Erik Beuck ${ }^{2}$ and Tayyab Sagheer ${ }^{3}$
}

${ }^{1}$ graduate of Department of Health Sciences, University of York, York, UK and an independent researcher. Egypt

${ }^{2}$ Lecturer at the Department of Political Science, University of Tennessee - Knoxville, Knoxville, USA. ${ }^{3}$ graduate of School of Politics and International Relations, Quaid e Azam University, Islamabad, Pakistan and an independent researcher.

\begin{abstract}
Since 2011, Syria has faced protests, upheaval, and civil war. During this long crisis, both state and nonstate actors have continuously attempted to exploit the situation to further their own interests. Since then, the civil war that resulted has led to widespread destruction, mass casualties, and extensive suffering among non-combatants who continue to live under daily threats related to the conflict. This paper examines the current conflict in Syria using news reports and documentaries with an aim to analyze how treaties and conventions of international law are being ignored on the ground regarding the protection of civilians. In the process of doing so, this paper will present evident violations committed by the combatants of state and nonstate forces. In addition, the strategic interests of international actors are discussed to the degree they present hurdles for the implementation of the protection of civilians in line with international humanitarian law. Moreover, it will demonstrate how international institutions have been unable to alleviate the suffering of the local population. We conclude with an examination of the role of international institutions and international actors in terms of their efforts to resolve the crisis.
\end{abstract}

Keywords: International Law; Humanitarian Law; Human Rights Violations; Non-Combatants; Civil War; Syrian Crisis.

\section{Introduction:}

The civil war in Syrian has now lasted for more than ten years and a concrete solution to the conflict has yet to be put forth by the international community, in large part due to the varied interests a number of states have in the outcome of the conflict. The Syrian Shia government is supported by Russia and Iran, whereas the opposition is backed by Turkey, a number of Western Powers, and Gulf states. In terms of Russian interests, Syria is an important ally and the location of its only remaining naval facility in the Mediterranean, at Tartus. Over the conflict, Russia has provided significant military support as well as conducted airstrikes on the Syrian regime's behalf. Iran considers Syria an important Shia partner in the region, a strategic relationship that extends back to the time of the Iran-Iraq War when Syria sided with it against Iraq. Since the start of the conflict, Iran has pledged billions of dollars in support of the regime, in order to help keep President al-Assad in power. In addition, there have been a number of Shia non-state actors who mobilized to fight alongside the military against rebel forces and strongholds. Standing against these forces are western states like the United Kingdom, United States, and France, all of whom have provided some degree of support to rebel forces. Syria's neighbour Turkey has also intervened in support of rebel forces, while also capturing areas of the northern border region of the country. Lastly, support from Saudi Arabia and other Gulf states has been provided to the opposition in an effort to counter the influence of Iran in the region. With all these contrarian interests in the outcome of the Syrian civil war, it is hardly surprising that the conflict has dragged on as long as it has. 
While this civil war continues, however, it is the civilian popular that continues to suffer the most, all the while hoping desperately for a peaceful resolution of the conflict. The lack of significant solutions and positive actions on the ground in Syria, neither by the United Nations (UN) nor by the international community as a whole, has allowed for violations of international humanitarian law to occur leading to the deaths of at least 100,000 people and the internal displacement of 6.5 million (UNOCHA, 2014) and a further 2.7 million people have fled to take refuge in neighbouring states (UNHCR, 2014) within the first few years of the conflict. In the face of no real progress being made to bring the conflict to a conclusion, these totals have ballooned to at least 400,000 dead, 5.6 million having fled the country, and more than 6.6 million are now internally displaced (UNHRC, 2021). As the civil war rages on, and the lack of respect of international humanitarian law continues, we can expect these numbers to continue to grow.

In this paper, we examine reports and media stories on the Syrian internal conflict to demonstrate the degree that those engaged in the conflict on the ground have violated international humanitarian law. Moreover, these violations of international law, including against international humanitarian law (IHL), international human rights law (IHRL), international refugee law (IRL), and international criminal law (ICL), will show support for our argument that not only is the Syrian government and its allies are to blame for these abuses, but their non-state opponents have engaged in such violations as well. In the pages to follow, we begin by presenting a summary of international law as it applies to civilians in conflict. From there, we present an overview of the conflict and cite specific examples of how international law has been violated by the various sides. We conclude with major takeaways and a discussion of the future of international humanitarian law in Syria.

\section{International Humanitarian Law and the Conduct of War}

There are number of important sources of international human rights law concerning the treatment of civilians during times of war. In general, modern international human rights are based in large part on the Universal Declaration of Human Rights (UDHR) adopted by the United Nations General Assembly in 1948 (OHCHR 1948). The UDHR outlines basic levels of civil, politics, economic, social and cultural rights that all human beings should be granted, and over time has been accepted as the source of fundamental norms concerning international human rights. Regarding times of conflict, the Geneva Conventions of 1949, especially Article 55 which covers the duties of an occupying power to provide food and medical supplies to the population if the stores there are inadequate, is one of the first international law conventions we will show has been violated by the actors engaged in the Syrian civil war. In addition, the customary international law Rules 53 to 56, which forbids the use of famine and the cutting off of relief supplies as a war strategy (Henckaerts, 2006), is another area in which violations have occurred.

The customary rules of international humanitarian law also apply to the treatment of particular groups and structures during an armed conflict, such as aid workers and their convoys, medical staff and the sites of healthcare services, religious officials and places of worship, news correspondents, and any structures related to education and civilization (see Rules 25 to 45 in Henckaerts, 2006). All those who fall under the umbrella of these protections should be treated as non-combatants and not subject to harm. Yet, during the course of the conflict in Syria, these protections have been violated again and again.

In addition, international humanitarian law has been put in place for the sake of safeguarding civilians. According to Henckaerts (2006), to do this effectively there is an initial focus on the differentiation between a fighter and a civilian, as well as structures associated with them. Civilians, as such, are defined as:

"Any person who is not a combatant. When civilians take a direct part in the fighting, they lose their protection from attack. (When there is any doubt about a person's status, he or she shall be considered to be a civilian)" (ICRC, 2009).

This means that any offensive strike, whether it is random or specifically aimed at civilians and their structures, is completely forbidden. Moreover, any strike targeted against military structures should be proceeded by general warning to the surrounding civilian population, so that the civilians might take precautions to save their lives (see Rules 1 to 24). Any violation of these rules is considered a violation of IHL. 
Tied in with this is the particular attention devoted to the protection of women and children, as they are often the most vulnerable population in wartime. The Convention on the Rights of the Child (CRC) (1989) was made in order to promote the rights of children in an attempt to protect them from harm in times of war. When combined with Article 25 of the UDHR (1948), which states that mothers and children are entitled to special care and assistance, the general status of women and children in a warzone should be a priority. Given that Syria is one of the state parties that has signed on to the CRC, any violations that occur by the acts of state forces open it up to investigation by the International Criminal Court (ICC). In addition, there are specific laws for the protection of refugees, enshrined in Article 33 of the Convention and Protocol Relating to the Status of Refugees, which states there is a prohibition of expulsion or return (refoulement) to the conflict zone from which they have fled. Specifically, no refugee would be returned to the frontiers of territories in which their lives or freedom might be under threat as a result of their race, religion, nationality, membership in a specific social group, or the holding of certain political opinions (UNHCR 2010).

In addition to the general rights outlined in the UHR and the specific conventions and rules set out to protect non-combatants and civilians in times of war, there are also international laws set out to preclude certain conflict activities. Foremost among these is the forbidding of certain types of weapons, such as those that are chemical, biological, poisonous, or incendiary in nature (Henckaerts, 2006). Although it can be argued the Syrian government is not a signatory for this convention, the use of such weapons still constitutes a war crime. According to international criminal law, the Rome Statute of the International Criminal Court (ICC, 1998) includes a clause in the Rome Statute (Article 87, 5 (b)) that states:

"Where a State not a party to this Statute, which has entered into an ad hoc arrangement or an agreement with the Court, fails to cooperate with requests under any such arrangement or agreement, the Court may so inform the Assembly of States Parties or, where the Security Council referred the matter to the Court, the Security Council (ICC, 1998)."

Essentially, this indicates that should information or evidence come to light of violations to the conduct of war with forbidden weapons, the ICC might inform the UNGA and UNSC that they might take direct actions against the party conducting the violations.

Related to rules discouraging the use of forbidden weapons, there are also efforts to protect prisoners of war from indignities and torture, such as cruel and inhumane punishment or outrages on the personal dignity of the individual (Henckaerts, 2006; OHCHR, 1948). Even though all these laws have been passed, have they actually be adhered to? Not in the case of the Syrian Civil War. Unfortunately, as will be gone into greater detail below, each of these protections has been violated to some degree in the past decade of the Syrian Civil War.

\section{The Syrian Civil War}

One of the most violent conflicts in the twenty-first century, the Syrian conflict started when antigovernment protests that started peacefully in 2011 were met with violence by the regime. In the following weeks and months, protests spread across all of Syria, culminating in demands for Bashar al-Assad to relinquish his power (Wimmen 2016). When al-Assad refused to acquiesce to these demands, a group of Army defectors soon organized as the Free Syrian Army (FSA) to begin launching attacks against government forces (Holliday 2011). Due to these events, the ICRC (2012) initially declared the situation on the ground as a Non-international armed conflict (NIAC), that is violent armed contention between the government and armed non-state actors within the country's borders (IHL 2006). Since then, the conflict has continued to expand with additional state and non-state actors getting involved. Russia and Iran have entered into the conflict on the side of the Syrian regime, while the US, Israel, Saudi Arabia, Qatar and Turkey have all supported the side of the rebels to varying degrees. There have even been a number of non-state actors that have entered into the conflict, either on the side of the regime as is the case for Hezbollah, the side of the rebels as it the case of Kurdish forces, or against all sides like Islamic state. 
Since the beginning of the conflict, significant amounts of infrastructure in the country have been destroyed. A UN satellite analysis (UN 2021) has suggested that almost 35,000 structures have been destroyed in Aleppo alone prior to the recapture of the city by government forces in 2016. Overall, reports suggest that 13.4 million people in Syria need humanitarian assistance and more than 12 million people are struggling to get enough food to survive (BBC, 2021). According to international humanitarian law and the law of armed conflict (ICRC 2004), conflicts like the one currently occurring in Syria are bound by a set of laws and rules to protect those who are not involved in waging the conflict. Despite what these international laws and rules set out to protect, the fact remains that there have been extensive violations of human rights in Syria over the course of the conflict. Though it is impossible to cover all the violations here, in the pages to follow we present a wide range of human rights violations that demonstrate that all sides of the civil war, at one time or another, have engaged in violations of human rights law over the course of the conflict.

\section{International Humanitarian and Human Rights Law Violations}

Since the start of the conflict, the Syrian government and its allies have engaged in a wide range of human rights abuses despite the protections offered to civilians and captured combatants under international law. So prevalent have these abuses been that a complete accounting will be impossible here. As such, a number of violations will presented demonstrating the range of abuses committed and the general timeframe in which they have occurred.

Near the start of the conflict, government forces utilized caterpillar heavy machinery to demolish civilian housing in certain areas, directly contributing to deaths and displacements of the population (Oweis, 2012). Beyond the use of heavy machinery, government forces have also been reported to have used bomb barrels dropped from helicopters, such as when they did so for five consecutive days over part of the city of Aleppo, even while the Geneva II Peace Conference on Syria was occurring in February of 2014 (Alarabiya, 2014). Ole Solvang from the Human Rights Watch reported that bakeries, which are considered a civilian structure, were targeted and attacked randomly by the government via bombs and guns, resulting in the death and injury of civilians very early in the conflict (Huffington, 2012b). These actions, and actions like them, indicate contempt for the progress of peace talks in the situation on the ground, as the destruction of civilian infrastructure accelerated over the course of the conflict. This is a clear violation of international law (see Article 53 of the 1949 Geneva Convention IV). Again, though Syria has not ratified the Additional Protocol II that applies to the protection of victims of non-international armed conflicts (ICRC, 1977), and as such there are some difficulties in legally applying the four Geneva conventions to a NIAC, the fact remains that customary international humanitarian law and Common Article 3 can apply to the forces affiliated with the Syrian government.

Another set of violations have occurred regarding healthcare services in Syria by the regime as well. In 2019-2020, the UN Human Rights Council (OHCHR 2020) stated that pro-government forces have repeated attacked medical facilities and medical personnel. Due to these actions, more than 16,000 doctors have fled the country, and even those that are left often are in hiding (Sparrow 2013). Worse for those that remain, assassinations of those simply doing there jobs, or the threat of being killed by Syrian military snipers or gunned down at checkpoints remains (Sparrow 2013). Compared to the scale of these actions, armed opposition groups, including ISIL, are only estimated as having killed 27 medical personal as of 2016 (Taub 2016).

Human rights abuses through torture and sexual assault have also been reported in abundance over the duration of the conflict by Syrian government forces. Records were leaked by a soldier dissident from the Syrian army who worked discreetly with armed non-state actors that showed proof that the Syrian army participated in "executing" and "torturing" of prisoners by electric shocks or hanging from their necks with photographic proof (Black, 2014a). Early in the conflict, a news report from the Wall Street Journal also revealed how the Syrian army violated the CRC by committing acts of imperious arrest, humiliation, and sexual assault (Lauria, 2011), and that minors were arrested and sent to prison, while also being prevented access to healthcare services (Head, 2012). The Human Rights Watch has collaborated reports that sexual 
crimes have been committed by Syrian government forces (Solvang, 2012, p.26-28). Even fleeing to neighboring Turkey was not enough to avoid the threat of rape, as refugees who successfully made it reported that more than 400 women had been sexually abused by Syrian army soldiers in 2011 (Abouzeid, 2011). In response to these acts, the Norwegian Foreign Minister of the time angrily declared that the rapes that had been so prevalent in the Bosnian War were repeating themselves in Syria (Brinkley, 2013). Women who are pregnant are also the subject of abuse and murder by Syrian government forces. By 2013, it was reported that such pregnant women were shot by government hunters (Bannerman, 2013; Alarabiya, 2013a), while on other occasions women were used as hostages to force the other side to free their prisoners or take force enemy combatants that were relatives of the hostages to surrender to Syrian government forces (Alarabiya, 2013b).

There have even been conduct of war violations in the form of the use of prohibited weapons, specifically chemical weapons. Bombs that cause incineration and burns had been used on a children's school in Aleppo, evidence emerging after the fact indicating their use through distinctive injuries to the civilians and the structure (HRW, 2013). A few days later in Damascus, MSF said that thousands of patients in hospitals there were being treated for neurotoxicity, symptoms indicative of poison gas attacks (Guardian, 2013). In response, the UN sent investigators to determine if prohibited weapons had indeed been used by Syrian government forces (UN, 2013) which was later found to be the case (UNODA 2013). Further collaboration later revealed that the two opposition-controlled areas around Damascus had been struck by rockets containing sarin, leading to the deaths of between 281 (MFAID, 2013) and 1729 people (Daily Star, 2013). Based on the calculated trajectories of the rockets flights, the Human Rights Watch determined that they could only have been launched from the state military base on Mount Oasioun, the main staging area for the Republican Guard 104 ${ }^{\text {th }}$ Brigade (BBC 2013). Those who have dismissed pursuing charges against the perpetrators of these heinous attacks point to the fact that, even though customary law prohibits the use of these weapons (Henckarts, 2006), because Syria is not a signatory of the Chemical Weapons Convention (1993) no legal action can be taken against the Syrian government forces that carried out the attack.

At this point it should also be noted that accusations of war crimes and human rights violations have been directed to the Syrian government's allies as well. Russia itself, the greatest supporter of al-Assad, has been alleged to have been responsible for a range of war crimes and human rights violations over the course of the conflict, ranging from conducting attacks on hospitals and rescue workers (Tomkiw, 2016; USA Today, 2016; Yeung, 2016), the use of cluster munitions in clear violation of the UN resolution 2139 (HRW 2016), the use of white phosphorus munitions that have burned civilians to death (Brookings, 2015; IBT, 2016) and even targeted airstrikes on densely populated civilian zones (Amnesty International, 2016; Edward, 2016; NYT, 2013). These latter actions would be confirmed by a 2020 report by the UN HRC, which laid responsibility for war crimes on the Russian Air Force for their indiscriminate bombings on civilian targets.

Though the litany of abuses discussed above presents the Syrian Government and its allies in a terrible light, unfortunately the fact remains that it is not the only side to engage in such abuses. The coalition of states allied with the United States who has supported the non-state democratically inclined opposition has also reportedly participated in human rights violations. According to Syrian Network for human Rights, there have been a reported 2,286 civilian deaths that are a direct result of US-led coalition airstrikes in their fight against ISIL up until September 2017 (HRW 2018). Moreover, Turkey in particular has been singled out as a violator of human rights and the inflictor of numerous abuses on the civilian population, especially those of Kurdish descent (UN HRC 2021). Indeed, their giving support to ISIL (Bekdil, 2015; Business Insider, 2015; Huffington Post, 2014) and other Islamist rebel groups (Fuller 2015; Jamestown Foundation 2015) in order to inflict greater damage against the Democratic Federation of Northern Syria, and consistent bombings of the population centres there by Turkish forces violated human rights as well (Ara News, 2016; Guardian, 2015).

Violations that did not discriminate between civilians and combatants were also conducted by the nongovernment fighters of the conflict. That being said, at least early in the conflict, it was noted by a UN inquiry that, while rebel forces had committed war crimes, they were not to the degree, scale, or frequency 
that the Syrian government forces had committed (Reuters 2012; ONCHR 2013). That being said, these forces were still alleged to have committed unlawful killings, acts of torture, kidnapping, and used children in the course of the conflict (UN HRC 2012). So numerous were these accounts early on in the conflict, Human Rights Watch issued an open letter to all opposition groups calling on the to cease unlawful practices like kidnappings, torture, and executions as they were violations of human rights (HRW 2012). Not long after this period, a short film was leaked from opposition groups showing one of their fighters' eating a piece of a heart or lung of a dead combatant in the Syrian army (Muir, 2013; Baker, 2013). Later, one nonstate group that labelled itself the Islamic Front bombed a hotel being used by Syrian government forces, even though it was in a densely populated civilian area, causing the injuries and deaths of many (Pleitgen 2014). Others have outright called for the killing of the civilian supporters of the Syrian government (Alqaradawi 2013). Such barbarous acts, though apparently uncommon, still seem to be occurring in the conflict. Despite pressure, these actions continued to occur, to the point that Amnesty International (2016) accused groups of continuing extrajudicial killings.

Humanitarian organizations that provide impartial assistance to those suffering in the conflict areas have also been targeted by non-state groups, such as what happened to the Syrian Arab Red Crescent who had several relief workers kidnapped and killed (Holmes and Nebehay, 2013). This incident led humanitarian non-governmental organizations (NGOs) to limit the entry of international relief workers into Syria and forced others to stop delivering assistance in the area where the incident occurred. Later this same year, a convoy carrying food assistance for those in need exploded and resulted in the deaths of two staff members (Sengupta, 2014a) as well as interrupted assistance to this area, a clear violation against Customary Rules 31 and 32 as well as Article 24 of the Geneva Convention (1949) that applies to aid workers and aid supplies to not be targeted (ICRC, 1949; Henckaerts, 2006).

As the conflict has dragged on, the recruitment of children to fight has increased as well. Though a violation of their rights, some minors favor signing up as it leads to their being provided with weapons that they would otherwise not get to protect themselves (Head, 2012; Sengupta, 2014b). By 2016, the UN had verified another 62 cases of child soldiers being recruited by the Free Syrian Army, another sign that the problem was not going to go away (UN 2016), and that each side would continue in the practice (Reuters 2016).

Lastly, extremist Islamist groups have engaged in systematic human rights abuses, including specifically targeting civilians (HRW 2016), some of which were because they were of Kurdish descent (UN HRC 2013). Perhaps the strongest of these groups in threat to the civilian population for a good portion of the conflict is ISIS, who began spreading rapidly throughout Syria in the middle of 2013 (BBC, 2014). Their efforts at controlling the northern Syrian cities led to their committing human rights abuses and extrajudicial killings in order to better cement their control of the region as well as impose their version of Islamic beliefs (Aarja, 2013).

\section{Commonalities in Abuses}

In the presentation of human rights violations above, it clear that certain types of attacks have been conducted by multiple sides in the conflict. The Guardian (2014) published a report originating from Physicians for Human Rights (PHR, 2014) that shows the medical personnel and infrastructure has been targeted since the start of the conflict by state, non-state, and anonymous actors, all of which is in breach of international humanitarian law. Estimated casualties before 2020 on medical personnel stand at roughly 923 , with those that have remained working suffering poor work conditions, seen the block of aid coming into the country, and dealt with food shortages (BBC 2021).

Children have been especially hard hit, with an estimate of 5,427 killed between 2014 and 219, averaging out to one death every 10 hours (Welle, 2020). In addition to these individual deaths, in 2019 alone there were more than 74 attacks launched on schools in Syria, resulting in more than 2 million children being forced to stay home, thereby getting behind in their educations (UNICEF 2020). The impacts of this is not limited to the boundaries of Syria either. Since the start of the Syrian crisis, there have been around 2.7 
million Syrians taking refuge in neighbouring countries such as Jordan, Lebanon, Turkey, Iraq, Egypt, and some European countries (UNHCR, 2014). Amnesty international reports that Syrians and Syrians of Palestinian origin have been being expelled out of Jordan back to the active war zones of Syria (Wilson, 2013). The same has happened in Lebanon, who justifies these expulsion actions by claiming the entry of these refugees is through illegitimate ways (Aluwaisheg, 2013; HRW, 2014; AFP, 2014). These actions extend to European countries like Greece and Bulgaria as well, as they too have more or less been forcibly sending Syrians who escaped to Europe back to Syria, sparking warnings by UNHCR and the European commission that such actions are against international law (Fotiades, 2013).

\section{Lack of Accountability}

Since the start of the conflict, there have been attempts by the UN to enforce the rules of international law on the actors engaged in fighting. One such attempt was early in 2014, when the UNSC agreed on Resolution 2139 (2014), which insisted that the process of cross-border and cross-line humanitarian assistance should be facilitated to allow the UN and aid agencies to reach those who are in high need of assistance. The Under-Secretary General for Humanitarian Affairs and Emergency Relief Coordinator said that consistent and frequent violations of international law by all parties cannot be tolerated, and that even though a war was going on, even wars have rules that need to be obeyed (Telegraph, 2014).

Despite these efforts, armed state and non-state actors on the ground have continued to hinder aid and the delivery of medical supplies, such as the polio vaccine, to people who are in dire need (Sengupta, 2014a). One such area especially hard hit by this was the Yarmouk Camp where more than 100,000 Palestinians lived. In 2014, due to the prevention of the delivery of aid by intense battles between the warring parties, the situation on the ground quickly worsened (Ahram, 2014). These two cases and others occurred two months after Resolution 2139 (2014) was signed, which gives a clear indication about the isolation between the international community and the actors engaged in the war occurring on the ground.

Moreover, UNSC efforts have been sharply truncated in effectiveness due to Russia consistently deploying their veto power on behave of Damascus in any effort to crack down on the human rights abuses and war crimes of the regime, especially when such votes were on topics related to harsher sanctions or military actions (Philips 2016). By July of 2020, Russia would vote in a way to protect the Syrian regime a total of 16 times, and would go on to frustrate Western and regional powers from efforts to facilitate al-Assad's departure from Syria via mediation efforts. Beyond political assistance, Russia has also helped the Syrian regime circumvent sanctions and extended a line of credit that they might continue purchasing the military equipment to continue to wage war on the opposition (Phillips 2016, p. 147-150).

The US is also somewhat to blame for the continuing human rights abuses on the ground due to its inconsistent foreign policies. Early on in the war, the US pressed for al-Assad to step down from power, and applied sanctions and material support to opposition forces in pursuit of this goal. Competing priorities such as the prevention of the use of chemical weapons, limiting the power of jihadist groups, and a nuclear disarmament agreement with Iran, however, meant that the US occasionally flipped priorities regarding alAssad (Phillips 2016). This was a continual source of frustration with the allied coalition. Without a consistent push by the US, and ineffective efforts by the UNSC, even the numerous UNSC resolutions aimed at changing the conduct of the conflict and pushing for the end of human rights abuses have been ineffective at best (see: UN SCOR 2014a, 2014b, 2014c, 2015, 2016, 2017, 2018a, 2018b, and 2020).

\section{Conclusion}

Though the examination of a small percentage of the human rights abuses to have occurred in the Syrian conflict until now, it should be clear to any observer that there has been no true adherence to international humanitarian law and that state and non-state actors alike have all engaged in violations across a wide range of types. The Syrian observatory of Human Rights, a UK based monitoring group, has estimated the numbers of deaths at 387,118, of whom 116,911 were civilians, by December 2020 (SOHR, 2020). The Violations Documentation Centre has given a slightly different estimate based on information provided by 
journalists, activists and reporters. According to them, the estimated death toll is slightly smaller at 226,374 but with a higher 135,634 civilians as casualties (VDC, 2020). UNICEF in turn has given an estimate of 12,000 children deaths by December 2020. Even if these numbers are off, the scale of the conflict and consistent report of abuses by the various sides over the past ten years has made it clear that international humanitarian law has proved ineffective in controlling the conduct of the conflict, and that no side is truly innocent of this.

What the consistent violations to international law by the parties engaged in the conflict show is that there remains significant obstacles to the implementation of international humanitarian law and the laws of war onto conflict zones, even when such a conflict has the attention of the international community, the UN, and the states of the UNSC. Because of the ineffective enforcement of these laws, civilians on the ground have suffered and likely will suffer under the conflict finally ends. Even when the conflict ends, however, the work of Antonio Cassese (2008) makes clear the complicated nature of the conflict, inconsistent surveillance of the different fighting groups, and lack of sufficient enforcement mechanisms to level legal penalties and punishments on those who violated international law will not be punished sufficiently to demonstrate that international humanitarian law is strong enough in the international system to discourage this conduct from happening again.

As it stands, a recent UN report puts even this failure of international law off for some time to come, as the large cities have been captured by Syrian government forces, while large portions of the countryside remain in the hands of various rebel groups, Kurdish forces, and jihadists (UN 2021). Though multiple international meetings have taken place in an attempt to bring the conflict to a close, al-Assad seems to be unwilling to negotiate with the opposition and non-state actors. Even the continued violations and threats posed to civilians caught up in the conflict, conveyed by clear evidence on the ground, doesn't seem to be enough to push for the various sides to make a more serious effort for peace. Without a clear political solution, it is possible, even likely, that the conflict will continue.

In order for progress to continue to be made regarding the enforcement and implementation of international humanitarian law, a number of things need to occur before the end of the conflict. First and foremost, the international community needs to more cohesively and comprehensively press for the end of attacks on civilians, civilian properties, and those providing aid on the ground. Secondly, this must go hand in hand with a surge in political will to hold any violators accountable for human rights abuses, regardless of the side they may be on. Lastly, following the end of the conflict, those human rights abuses that occurred must be investigated and charges brought against those who committed them, again regardless of the side they fought on. Only when these three things have been done by the international community will international humanitarian law be seen as still making a difference in warzones. If these steps are not taken, however, the likelihood that future human rights abuses like those occurring in Syria taking place in the warzones of the future become that much more likely.

\section{$\underline{\text { References }}$}

1. Aarja, H. 2013. ISIS enforces strict religious law in Raqqa.

2. Abouzeid, Rania. 2011. "Syria: In Search of the Rape Victims Among the Refugees." Accessed at: http://content.time.com/time/world/article/0,8599,2078622,00.html.

3. AFP. 2014. Lebanon rapped for blocking Palestinians fleeing Syria. [Online]. Available at: http://www.afp.com/en/node/2360176.

4. Ahram. 2014. Shooting at Yarmouk camp interrupts relief work: UNRWA.

5. Alarabiya. 2013a. Syria snipers targeted pregnant women, says British surgeon.

6. Alarabiya. 2013b. Report: rape used as weapon of war against Syria women.

7. Alarabiya. 2014. NGO: 246 dead in 5 days of barrel bombing of Syria's Aleppo.

8. Alqaradawi, Y. 2013. Yusuf al- Qaradawi - Kill All Pro Syrian Government Supporters. 
9. Aluwaisheg, A. A. 2013. Syrian refugees in Lebanon and forced repatriation.

10. Amnesty International. 2016a. "Syria: Abductions, torture and summary killings at the hands of armed groups." Accessed at: https://www.amne sty.org/en/latest/news/2016/07/syria-abductionstorture-and-summary-killings-at-the-hands-of-arm ed-groups/.

11. Amnesty International. 2016b. "Syrian and Russian forces have deliberately targeted hospitals near Aleppo." Accessed at: https://www.amnesty.org.uk/press-releases/syrian-and-russian-forces-havedeliberately-targeted-hospitals-near-aleppo.

12. Ara News. 2016. "Turkey strikes Kurdish city of Afrin northern Syria, civilian casualties reported." Accessed at: http://aranews.net/2016/02/turkey-bombs-kurdish-city-of-afrin-northern-syria-civiliancasualties-reported/.

13. Baker, A. 2013. Exclusive: 'We Will Slaughter All of Them.' The Rebel Behind the Syrian Atrocity Video.

14. Bannerman, L. 2013. 'Assad's snipers' target unborn babies.

15. BBC. 2013. "Syria chemical attacks: What we know." Accessed at: https://www.bbc.co.uk/news/world-middle-east-23927399.

16. BBC. 2014. Profile: Islamic State in Iraq and the Levant (ISIS). [Online]. Available at: http://www.bbc.com/news/world-middle-east-24179084.

17. BBC News. 2021. https://www.bbc.com/news/world-middle-east-35806229.

18. Bekdil, Burak. 2015. "Turkey's Double Game with ISIS." Accessed at: http://www.meforum.org/5317/turkey-isis.

19. Black, I. 2014. Syrian regime document trove shows evidence of 'industrial scale' killing of detainees. [Online]. Available at: http://www.theguardian.com/world/2014/jan/20/evidenceindustrial-scale-killing-syria-war-crimesAvailable

at: http://www.theguardian.com/world/interactive/2014/jan/20/torture-of-persons-under-current-syrianregime-report.

20. Borger, Julian. 2020. "Russia committed war crimes in Syria, finds UN report." Accessed at: https://ww w.theguardian.com/world/2020/mar/02/russia-committed-war-crimes-in-syria-finds-unreport.

21. Brinkley, Joel. 2013. "War Rape: Rwanda, Bosnia, and Now Syria." Accessed at: http://www.worldaffairsjournal.org/blog/joel-brinkley/war-rape-rwand a-bosnia-and-now-syria.

22. Brookings Institution. 2015. "An internal struggle: Al Qaeda's Syrian affiliate is grappling with its identity." Accessed at: http://www.brooking s.edu/blogs/markaz/posts/2015/05/31-syria-isis-lister.

23. Business Insider. 2015. "Senior Western official: Links between Turkey and ISIS are now 'undeniable'." Accessed at: http://www.busine ssinsider.com/links-between-turkey-and-isis-are-nowundeniable-2015-7.

24. Cassese, A. 2008. Current Challenges to IHL [Online]. The Graduate Institute. Available at: http://www.dailymotion.com/video/x7pf15_antonio-cassese-part-

i_news?from_related=related.page.int.meta2only.1035777b9b93a454219db3bb74d37d5d140030859.

25. Charbonneau, L. 2013. UNESCO sounds alarm about illicit Syria archeology digs.

26. Daily Star. 2013. "Bodies still being found after alleged Syria chemical attack: opposition." Accessed at: http://www.dailystar.com.1 b/News/Middle-East/2013/Aug-22/228268-bodies-still-being-foundafter-alleged-syria-chemical-att ack-opposition.ashx\#axzz2chzutFua.

27. Fotiades, A. 2013. Syrian Refugees Illegally Pushed Back.

28. France Diplomatie - MFAID. 2013. "Syria/Syrian chemical programme - National executive summary of declassified intelligence." Accessed http://www.diplomatie.gouv.fr/en/IMG/pdf/Syrian_Chemical_Programme.pdf.

29. Fuller, Graham E. 2016. "How Can Turkey Overcome Its Foreign Policy Mess?" Accessed at: https://lobelog.com/how-can-turkey-overc ome-its-foreign-policy-mess/.

30. Hafiz, Y. 2013. Syria Conflict Destroys Churches \& Mosques, Desecrates Icons (PHOTOS). [Online]. Available at: http://www.huffingtonpost.com/2013/08/06/syria-conflict-destroys-mosqueschurches_n_3709262.html. 
31. Hawar News. 2020. "Reports: Afrin women enslaved, transferred to Libya by mercenaries" Accessed at: https://www.hawarnews.co m/en/haber/reports-afrin-women-enslaved-transferred-to-libya-bymercenaries-h21685.html.

32. Head, J. 2012. "Syria authorities target children, says UN rights chief."

33. Henckaerts, J. 2006. Annex. List of Customary Rules of International Humanitarian Law. ICRC.

34. Holliday, J. 2011. "The Struggle for Syria in 2011." Institute for the Study of War: Middle East Security Report no. 2.

35. Holmes, J. 2013. Does the UN's Responsibility to Protect necessitate an intervention in Syria? [Online]. Available at: http://www.theguardian.com/commentisfree/2013/aug/28/syria-interventionun-responsibility-to-protect.

36. Holmes, O. and Nebehay, S. 2013. Some aid workers freed in Syria, risks to humanitarian effort grow.

37. Huffington Post. 2014. "Research Paper: ISIS-Turkey Links." Accessed at: http://www.huffingtonpost.com/david-1-phillips/research-pap er-isis-turke_b_6128950.html.

38. Human Rights Watch. 2012. "Syria: Armed Opposition Groups Committing Abuses." Accessed at: https://www.hrw.org/news/2012/03/20/syri a-armed-opposition-groups-committing-abuses.

39. Human Rights Watch. 2013. Syria violates international humanitarian law. Mail and Guardian, [Online]. Available at: http://mg.co.za/multimedia/2013-11-18-syria-violates-internationalhumanitarian-law/.

40. Human Rights Watch. 2014. "Lebanon: Palestinians Barred, Sent to Syria."

41. Human Rights Watch. 2015. "Russia/Syria: Extensive Recent Use of Cluster Munitions | Human Rights Watch." Accessed at: https://www.hr w.org/news/2015/12/20/russia/syria-extensive-recentuse-cluster-munitions.

42. Human Rights Watch. 2016. "World Report 2016: Syria Events of 2015" (https://www.hrw.org/world-report/2016/country-chapter s/syria). Human Rights Watch.

43. Human Rights Watch. 2018. "Syria: Events of 2017." Accessed at: https://www. hrw.org/worldreport/2018/country-chapters/Syria.

44. Huffington Post. 2012. "Syria: Government attacking Bread Lines."

45. ICC. 1998. "Rome Statute of the International Criminal court [Online]. ICC." Available at: http://www.icc-cpi.int/nr/rdonlyres/ea9aeff7-5752-4f84-be940a655eb30e16/0/romestatuteenglish.pdf.

46. ICRC. N/A. "Syria - Treaties and State Parties to such treaties [Online]. ICRC." Available at: http://www.icrc.org/applic/ihl/ihl.nsf/vwTreatiesByCountrySelected.xsp?xp_countrySelected=SY\&n $\mathrm{v}=4$.

47. ICRC. “The Geneva conventions of 12 August 1949.” ICRC.

48. ICRC. 1949. "The Geneva conventions of 12 August 1949.” ICRC.

49. ICRC. 1977. "Protocol Additional to the Geneva Conventions of 12 August 1949, and relating to the Protection of Victims of Non-International Armed Conflicts (Protocol II), 8 June 1977." ICRC.

50. ICRC. 1993. "Chemical Weapons Convention [Online]. ICRC." Available at: http://www.icrc.org/applic/ihl/ihl.nsf/Treaty.xsp?documentId=9D3CCA7B40638EF5C12563F6005F 63C5\&action=openDocument.

51. ICRC. 2004. "What is International Humanitarian Law?" ICRC.

52. ICRC. 2009. "Terms used in Exploring Humanitarian Law.” ICRC.

53. ICRC. 2012. "Syria: ICRC and Syrian Arab Red Crescent maintain aid effort amid increased fighting."

54. ICRtoP. 2013. "Q\&A: THE RESPONSIBILITY TO PROTECT (RtoP) AND SYRIA. [Online]." Available at: http://responsibilitytoprotect.org/FINAL\%20Syria\%20Q\%20and\%20A.pdf.

55. IIHL. 2006. "The Manual on the Law of Non-International Armed Conflict With Commentary IIHL."

56. International Business Times. 2016. "Syria: Kurds close in on Isis capital of Raqqa as ceasefire looms." Accessed at: http://www.ibtimes.co.uk/syria-k urds-close-isis-capital-raqqa-ceasefire-looms1546239. 
57. Jamestown Foundation. 2015. "The Rise of Jaysh al-Fateh in Northern Syria." Accessed at: http://www.jamestown.org/single/?tx_ttnews\%5btt_news\%5d=44027.

58. Lauria, J. 2011. "More Than 250 Children Among Dead, U.N. Says."

59. Muir, J. 2013. "Outrage at Syrian rebel shown 'eating soldier's heart'."

60. New York Times. 2013. "A Very Busy Man Behind the Syrian Civil War's Casualty Count." Accessed at: https://www.nytimes.com/2013/04/10/world/middleeast/the-man-behind-the-casualtyfigures-in-syria.html?pagewanted=all\&r=0.

61. OHCHR. 1948. "The Universal Declaration of Human rights [Online]. UN, UDHR." Available at: http://www.un.org/en/documents/udhr/index.shtml.

62. OHCHR. 2020. "Report of the Independent International Commission of Inquiry on the Syrian Arab Republic." Accessed at: https://www.ohchr.org/Documents/HRBodies/HRCouncil/CoISyria/A_HRC_43_57_AEV.docx.

63. OPCW. "Member States. OPCW."

64. Oweis, K. Y. 2012. Syria army destroys houses in "collective punishment".

65. Phillips, Christopher. 2016. The Battle for Syria: International Rivalry in the New Middle East. London, UK: Yale University Press.

66. PHR. 2014. A Map of Attacks on Health care in Syria. The GuardianPhysicians for Human Rights

67. Pleitgen, F. 2014. Syrian rebels bomb Aleppo hotel [Online]. CNN. Available at: http://edition.cnn.com/video/data/2.0/video/world/2014/05/08/id-pleitgen-syria-aleppo-hotelbombed.cnn.html.

68. Reuters. 2012. "Syrian air raid kills 30 in rebel-held town -activists." Accessed at: https://www.reuters.com/article/syria-crisis-id USL6E8JECO820120815.

69. Reuters. 2016. "Syrian war creates child refugees and child soldiers: report." Accessed at: https://www.reuters.com/article/us-mid east-crisis-syria-children-idUSKCN0WG0R0.

70. Sengupta, S. 2014a. U.N. Finds Humanitarian Aid Still Blocked in Syria, Despite Resolution.

71. Sengupta, S. 2014b. U.N. Report Details Abuse of Children in Syrian War.

72. SOHR. 2016. "About 65 casualties and injuries in shelling and launching explosive cylinders on Sheikh Maqsood neighborhood." Accessed at: http://www.syriahr.com/en/2016/04/06/45704.

73. Solvang, Ole. 2012. "Torture archipelago: arbitrary arrests, torture, and enforced disappearances in Syria's underground prisons since March 2011." Accessed at: https://www.hrw.org/sites/default/files/reports/syr ia0712webwcover.pdf.

74. Sparrow, Annie. 2013. "Syria's Assault on Doctors." Accessed at: http://www.nybooks.com/daily/2 013/11/03/syria-assault-doctors/?insrc=rel.

75. Syrian Observatory for Human Rights. 2016. "Russia's airstrike on a Syrian hospital was no accident. It was a cold-blooded, targeted attack." Accessed at: http://www.syriahr.com/en/2016/02/16/44200.

76. Taub, Ben. 2016. "Syria's War on Doctors." Accessed at: (http://www.newyorker.com/magazine/2016/0 6/27/syrias-war-on-doctors). The New Yorker.

77. Telegraph. 2014. UN chief calls for end to 'flagrant violation of humanitarian laws' in Syria. [Online]. Available at: http://www.telegraph.co.uk/news/worldnews/middleeast/syria/10637729/UNchief-calls-for-end-to-flagrant-violation-of-humanitarian-laws-in-Syria.html.

78. The Guardian. 2013. Syrian hospitals treated thousands for poison gas symptoms, says charity. The Guardian.

79. The Guardian. 2014. Assad Regime targets Syrian Healthcare System. [Online]. Available at: http://www.theguardian.com/world/2014/may/14/assad-regime-targets-syrian-health-care.

80. The Guardian. 2015. "Turkey accused of shelling Kurdish-held village in Syria." Accessed at: https://www.theguardian.com/world/201 5/jul/27/turkey-shells-kurdish-held-village-in-syria.

81. Tomkiw, Lydia. 2016. "Who Bombed Doctors Without Borders Hospital In Syria? MSF Slams 'Deliberate' Airstrike." Accessed at: http://www.ibtimes.com/who-bombed-doctors-without-bordersh ospital-syria-msf-slams-deliberate-airstrike-2307826.

82. UN. "Unanimously approved, Security Council resolution demands aid access in Syria. [Online]." Available http://www.un.org/apps/news/story.asp?NewsID=47204\&Cr=syria\&Cr1=\#.U3mk7tJWun-. 
83. UN. 1989. "Convention on the Rights of the Child (CRC) [Online]. UN Treaty collection." Available at: https://treaties.un.org/doc/Publication/MTDSG/Volume\%20I/Chapter\%20IV/IV-11.en.pdf.

84. UN. 2013. "Syria: Ban sending official request to allow UN probe of alleged chemical weapons use. [Online]." Available at: http://www.un.org/apps/news/story.asp?NewsID=45677\#.U3nNi9JWun8.

85. UN. 2014. "United Nations Security Council Resolution 2139 [Online]. UN Security Council." Available at: http://www.un.org/en/ga/search/view_doc.asp?symbol=S/RES/2139(2014).

86. UNICEF. N/A. "Syria Crisis Fast Facts." Accessed at: https://www.unicef.org/mena/reports/syriacrisis-fast-facts.

87. UNESCO. 2014. "The destruction of Syria's cultural heritage must stop".

88. UNHCR. 2010. Convention and Protocol Related to the Status of Refugees. UNHCR.

89. UNHRC. 2012. "Periodic Update of the Independent International Commission of Inquiry on the Syrian Arab Republic." Accessed at: http://www.ohchr.org/Documents/HRBodies/HRCouncil/SpecialSession/CISyria/Periodic UpdateCISyria.pdf.

90. UNHRC. 2013. "Independent International Commission of Inquiry on the Syrian Arab Republic, February 2013." Accessed at: http://www.ohchr.org/EN/HRBodies/HRC/IICISyria/Pages/IndependentInternationalCommission.a $\operatorname{spx}$.

91. UNHRC. 2014. Syria Regional Refugees Statistics [Online]. UNHCR. Available at: http://data.unhcr.org/syrianrefugees/regional.php.

92. UNHRC. 2021. Report of the Independent International Commission of Inquiry on the Syrian Arab Republic. UNHCR. Available at: https://undocs.org/en/A/HRC/48/70.

93. UNOCHA. 2014. Key Figures of Syrian Crisis [Online]. UN OCHA. Available at: http://syria.unocha.org/.

94. UNODA. 2013. United Nations Mission to Investigate Allegations of the Use of Chemical Weapons in the Syrian Arab Republic. [Online]. Available at: https://unoda-web.s3.amazonaws.com/wpcontent/uploads/2013/12/report.pdf.

95. UNSCOR. 2014a. 69th Session, 7116th meeting, UN Doc S/Res/2139 (February 22, 2014). Accessed at: https://undocs.org/S/RES/2139(2014).

96. UNSCOR. 2014b. 69th Session, 7216th meeting, UN Doc S/Res/2165 (July 14, 2014). Accessed at: https://undocs.org/S/RES/2165(2014).

97. UNSCOR. 2014c. 69th Session, 7344th meeting, UN Doc S/Res/2191 (December 17, 2014). Accessed at: https://undocs.org/S/RES/2191(2014).

98. UNSCOR. 2015. 70th Session, 7595th meeting, UN Doc S/Res/2258 (December 22, 2015). Accessed at: https://undocs.org/S/RES/2191(2015).

99. UNSCOR. 2016. 71th Session, 7849th meeting, UN Doc S/Res/2332 (December 21, 2016). Accessed at: https://undocs.org/S/RES/2332(2016).

100. UNSCOR. 2017. 72th Session, 8141th meeting, UN Doc S/Res/2393 (December 19, 2017). Accessed at: https://undocs.org/S/RES/2393(2017).

101. UNSCOR. 2018a. 73th Session, 8188th meeting, UN Doc S/Res/2401 (February 24, 2018). Accessed at: https://undocs.org/S/RES/2401(2014).

102. UNSCOR. 2018b. 73th Session, 8423th meeting, UN Doc S/Res/2449 (December 13, 2018). Accessed at: https://undocs.org/S/RES/2449(2018).

103. UNSCOR. 2020. 75th Session, 8700th meeting, UN Doc S/Res/2504 (January 10, 2020). Accessed at: https://undocs.org/S/RES/2504(2014).

104. UNSIMIS. (2012a). Six point plan to end the conflict in Syria. [Online]. Available at: http://www.un.org/en/peacekeeping/documents/six_point_proposal.pdf.

105. UNSIMIS. 2012b. "Statement attributable to the Head of the UN Supervision Mission in Syria, General Robert Mood. [Online]." Available at: http://www.un.org/en/peacekeeping/missions/unsmis/documents/press_mood_16062012.pdf. 
106. USAToday.com. 2016. "UN: Nearly 50 civilians killed in Syria by airstrikes on hospitals, schools." Accessed at: https://www.usatoday.co m/story/news/world/2016/02/15/doctors-withoutborders-supported-clinic-hit-airstrikes/80394268/.

107. Wilson, N. 2013. Amnesty International: Jordan is deporting Syrian refugees.

108. Wimmen, H. 2016. Syria's Path from Civic Uprising to Civil War. Washington, DC: Carnegie Endowment for International Peace.

109. World Report. 2020 https://www.hrw.org/world-report/2020/country-chapters/syria\#.

110. Yeung, Peter. 2016. "Russia committing war crimes by deliberately bombing civilians and aid workers, says Amnesty International | Middle East | News." Accessed at: https://www.independent.co.uk/news/world/mid dle-east/russia-civilians-war-crimes-amnestyinternational-a6887096.html.

Funding Statement: The Authors have covered all the expenses and no external sources of funding have been used in this research.

\section{Acknowledgements:}

${ }^{1}$ Author: This work would not have been possible without the support, guidance and patience of Dr. Jo Rose and Dr. Janaka Jayawickrama during my study, and their understanding that a part-time Masters degree is a long and challenging commitment that can be distracted and interrupted by our current field jobs in remote areas. I would like to thank the University of York Writing Centre for providing indispensable guidance towards improving my writing skills during my Masters degree study. Finally, many thanks and my gratitude must be given to Mr. Danny Singh, my first-year tutor who supported me personally to overcome some problems occurred at the beginning of the first year, and taught me step by step on how to write a proper academic paper until I passed my degree.

${ }^{2}$ Author: I would to extend my thanks to both Ahmed and Tayyab for bringing me onto this interesting project. In addition, I would also like to extend my gratitude to the anonymous reviewers who took the time to review this article.

${ }^{3}$ Author: First of all, I would like to give thanks to Almighty Allah for giving me the strength and guidance in writing this article. He is the One who has bestowed me with the wisdom and ability to do so. I express my gratitude to my parents for always being supportive of my education. I also take this opportunity to acknowledge everyone in my large extended family. They are the real strength and pride of my life; without their prayers and unconditional love, nothing would have been possible.

Conflict of Interests Declaration: The authors have no conflicts of interest to declare. 